\title{
New records and diet reconstruction using dental microwear analysis for Neolicaphrium recens Frenguelli, 1921 (Litopterna, Proterotheriidae)
}

\author{
*Andrea Corona ${ }^{1}$, Martín Ubilla ${ }^{1}$, Daniel Perea ${ }^{1}$ \\ ${ }^{1}$ Departamento de Paleontología, Instituto de Ciencias Geológicas, Facultad de Ciencias, Universidad de la República, Iguá 4225, \\ 11400, Montevideo, Uruguay. \\ acorona@fcien.edu.uy; martinubilla@gmail.com; perea@fcien.edu.uy \\ * Corresponding author: acorona@fcien.edu.uy
}

\begin{abstract}
Neolicaphrium recens is the only survivor proterotherid in the Quaternary of South America, of which few fossil records from Argentina, Uruguay and probably Brazil are known. In this paper we describe new cranial remains with teeth series of $N$. recens from Artigas Department, Uruguay (Sopas Formation, Late Pleistocene), and previously published remains were reinterpreted and assigned to $N$. recens. We performed a dental microwear study of the seven most complete adult specimens from Argentina and Uruguay. The dental facets of interest were molded with silicone dental impression; the moulds were filled with epoxy resin and observed in a stereomicroscope. The paracone of M2 and the protoconid of $\mathrm{m} 2$ were photographed and the images digitally processed and studied. The results showed a high relative percentage of pits (scars of soft plants) on scratches (grooved pattern caused by silicophytoliths of grasses), indicating that the analyzed specimens were browsers, and their diet probably included fleshy leaves, buds and stems of trees and shrubs. These new data are consistent with previous results of carbon and oxygen isotopes studies and with inferences based on the associated fauna of $N$. recens in Uruguay, indicating for the Sopas Formation open to semi open grassland with forested areas, resembling a savanna. This study suggests some woodland environments for all the range of geographical distribution of the taxon.
\end{abstract}

Keywords: Feeding ecology, Paleoenvironment, Microwear, Quaternary, Sopas Formation, Uruguay.

RESUMEN. Nuevos registros y reconstrucción de dieta a través de análisis del microdesgaste dentario de Neolicaphrium recens Frenguelli, 1921 (Litopterna, Proterotheriidae). Neolicaphrium recens es el único proterotérido registrado en el Cuaternario de Sudamérica, del cual se conocen pocos ejemplares de Argentina, Uruguay y probablemente Brasil. En este trabajo se describen nuevos restos craneales con dentición de $N$. recens proveniente del departamento de Artigas, Uruguay (Formación Sopas, Pleistoceno Tardío), y restos fósiles previamente publicados fueron reinterpretados y asignados a $N$. recens. Se realizó un estudio del patrón de microdesgaste dentario de los siete especímenes adultos más completos de Argentina y Uruguay. Las facetas de interés se moldearon con silicona para impresión dental; los moldes se rellenaron con resina epoxi y se observaron en estereomicroscopio. El paracono de M2 y el protocónido de $\mathrm{m} 2$ fueron fotografiados y las imágenes estudiadas digitalmente. Los resultados mostraron un mayor porcentaje relativo de hoyos (cicatrices de vegetales blandos) sobre estrías (patrón de surcos causado por silicofitolitos de gramíneas), lo que indica que los ejemplares analizados fueron ramoneadores y su dieta probablemente incluyó hojas carnosas, yemas y tallos de árboles y arbustos. Estos nuevos datos son consistentes con los resultados previos de estudios de isótopos de carbono y oxígeno y con inferencias basadas en la fauna asociada a N. recens en Uruguay, indicando para la Formación Sopas, pastizales abiertos a semiabiertos, con áreas forestadas, semejante a una sabana. Este estudio permite sugerir ambientes con áreas boscosas para todo el rango de distribución geográfica del taxón. 


\section{Introduction}

The Litopterna Ameghino, 1889 is one of the native mammalian groups of South America with a wide distribution limited to this continent. They are diverse ungulates that appear in the Early Paleocene, showing a great diversification until the Pliocene when they dramatically decline. They got extinct during the Late Pleistocene/Early Holocene (Prado et al., 2015). The Proterotheriidae is the most diverse family of litopterns, represented by small to medium size cursorial ungulates, with a "horse-like" tendency to the monodactyly - long metapod III, digits II and IV reduced and digit I and V lost. Despite the fact that Frenguelli (1921) described Neolicaphrium recens found in Pleistocene sediments from Argentina, at that time this family was believed extinct in the Pliocene. New findings in Uruguay (Perea et al., 1995) suggested the presence of Neolicaphrium recens in the Quaternary, later confirmed by more collected and reviewed material from north center Argentina, northern Uruguay and probably in southern Brazil (Tauber, 2000; Bond et al., 2001; Scherer et al., 2009; Vezzosi et al., 2009; Ubilla et al., 2011; Luna et al., 2015; Schmidt et al., 2016; Vezzosi, 2016; Gaudioso et al., 2017).

Fossils attributed to $N$. recens are scarce and fragmented and most of them correspond to mandible remains. Ubilla et al. (2011) described the first cranial remains for the taxon, making progress in the cranial anatomy and expanding the diagnosis. Despite this, the knowledge of its paleobiology is poor. Indirect evidence from the faunal associations that $N$. recens integrated in Uruguay, indicate that the species was restricted to relative humid and forested environments linked to climatic conditions related to the Marine Isotopic Stage 3 (MIS-3, Late Pleistocene) (Ubilla et al., 2016). In this context, the tooth microwear pattern in $N$. recens provides the first and novel information in paleoenvironmental interpretations in Pleistocene endemic ungulates.

The aim of this study is to describe a new specimen of $N$. recens, improving the knowledge of this protherotherids. Furthermore, we analyze the dental microwear pattern of $N$. recens in order to recognize its dietary preferences. We analyze the congruence with results of previous carbon and oxygen isotopic studies (Morosi and Ubilla, 2017), but expanding the sample and with a greater coverage of the known geographical distribution for the taxon.

\section{Geographical and geological settings}

Neolicaphrium recens have been recorded for the first time in Córdoba Province, Argentina (Frenguelli, 1921), although the finding of this proterotherid in Quaternary deposits, which was believed extinct in the Pliocene, was not accepted definitely until the current century (Bond et al., 2001). Álvarez (1974) found a mandibular remain that is certainly similar to the specimen described by Frenguelli, which came from Pleistocene beds of the Toropí Creek, Corrientes Province, but she interpreted this fossil as removed within those deposits. Tauber (2000) described carpal and metacarpal bones of $N$. recens from Pleistocene deposits of Córdoba and Vezzosi et al. (2009) indicated evidence of an immature specimen of $N$. recens in Santa Fe Province (Tezanos Pinto Formation, Late Pleistocene-Early Holocene). Later, Luna et al. (2015) communicated the finding of dental remains in Córdoba but, unfortunately, there is no precise stratigraphic provenance. Schmidt et al. (2016) shown new materials from Pleistocene deposits of Córdoba, including postcranial remains, and Gaudioso et al. (2017) present the first record for Santiago del Estero Province, from layers of the same age. In southern Brazil (Rio Grande do Sul State) there are some postcranial materials from Pleistocene deposits that probably correspond to $N$. recens, although more findings are necessary to confirm this hypothesis (Scherer et al., 2009).

The specimens from Uruguay (Bond et al., 2001; Ubilla et al., 2011; and the new material here described) have been found in Late Pleistocene sediments of the Sopas Formation (Anton, 1975) (Fig. 1). In recent years, the knowledge of the fossil content of this lithostratigraphic unit has been increased, as well as the mammal associations, and its value as biostratigraphic, paleoecological and paleoenvironmental source of information. The Sopas Formation crops out in northern Uruguay (Artigas, Salto, Tacuarembó, Paysandú and Río Negro Departments) alongside creeks and rivers (Ubilla et al., 2004). The deposits includes medium to coarse-grained sandy and conglomerate basal levels belonging to fluvial facies overlied by mudstones and siltstones linked to floodplains and paleosoils. An update of the fossiliferous content of the Sopas Formation and the numerical ages obtained until now, linked to the stratigraphic columns of main localities, can be found in Ubilla and Martínez 


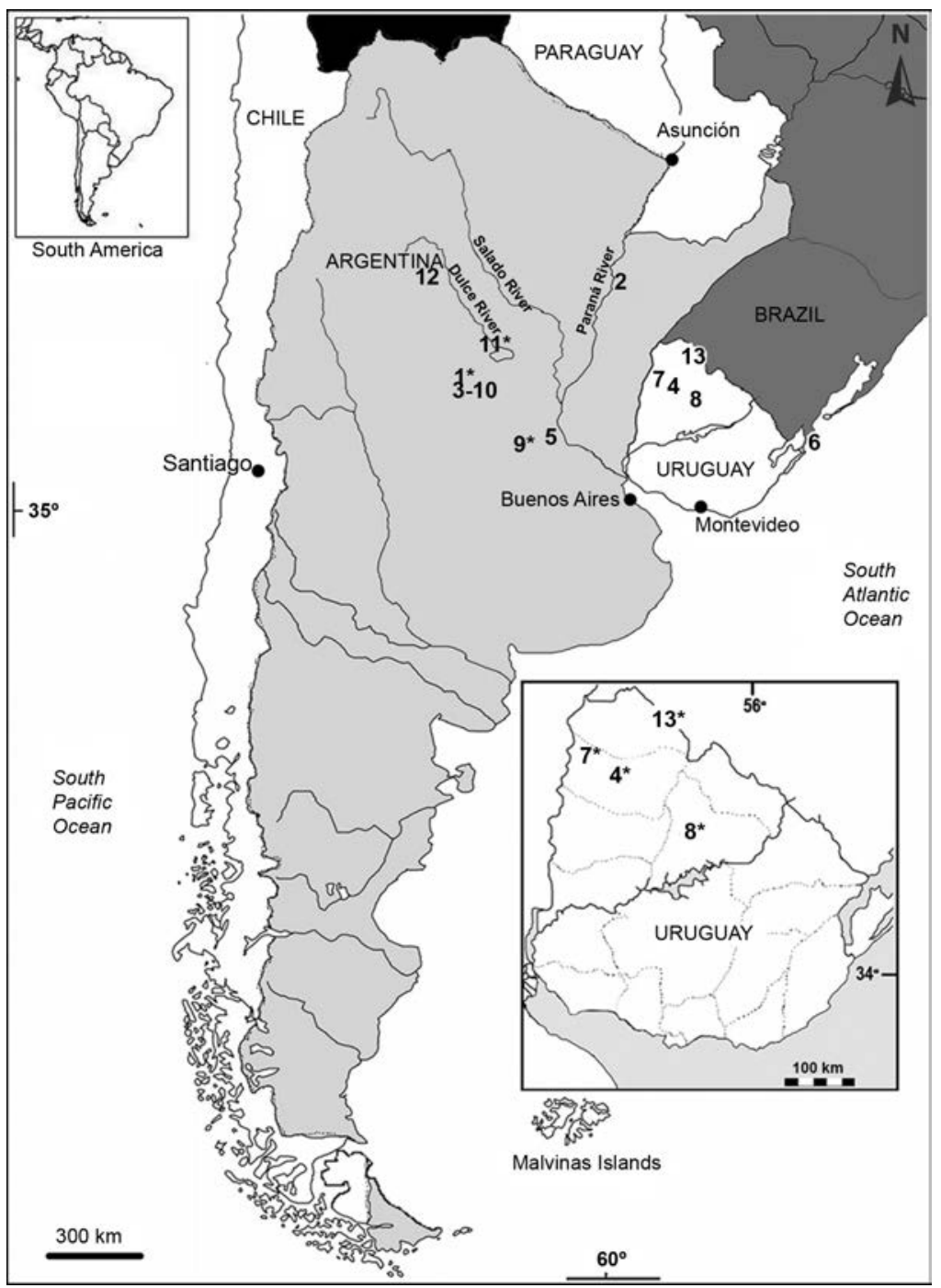

FIG. 1. Geographic provenance of Neolicaphrium recens in chronological order of publication date. The remains here described are included. 1: Córdoba City; 2: Toropí Creek, Corrientes, 3: Corralito, Córdoba; 4: Sopas Creek, Salto; 5: Mugueta Village, Santa Fe; 6: Santa Vitoria do Palmar, Río Grande do Sul; 7: Arapey Grande River, Salto; 8: Malo Creek, Tacuarembó; 9: Coronda River, Santa Fe; 10: Corralito, Córdoba; 11: Mar Chiquita, Córdoba; 12: Dulce River, Santiago del Estero; 13: Cuareim River, Artigas. The asterisk indicates the specimens used for this work. The square box represents a zoom, where the Uruguayan specimens used in this analysis are indicated.

(2016) and Ubilla et al. (2016). The figure 2 shows a detail of the stratigraphic section from where the new Neolicaphrium recens material described in this work comes from. In summary, Neolicaphrium recens exhibit a distribution pattern in the Argentinian center-northern and northern Mesopotamia, northern Uruguayan and southern Brazilian Pampean area during the Pleistocene sensu lato.

\section{Materials and methods}

\subsection{Theorical framework}

The microwear of tooth enamel is the abrasion produced during the mastication by the different food items, generating wear surfaces (Teaford and Oyen, 1989; Solounias and Semprebon, 2002). 


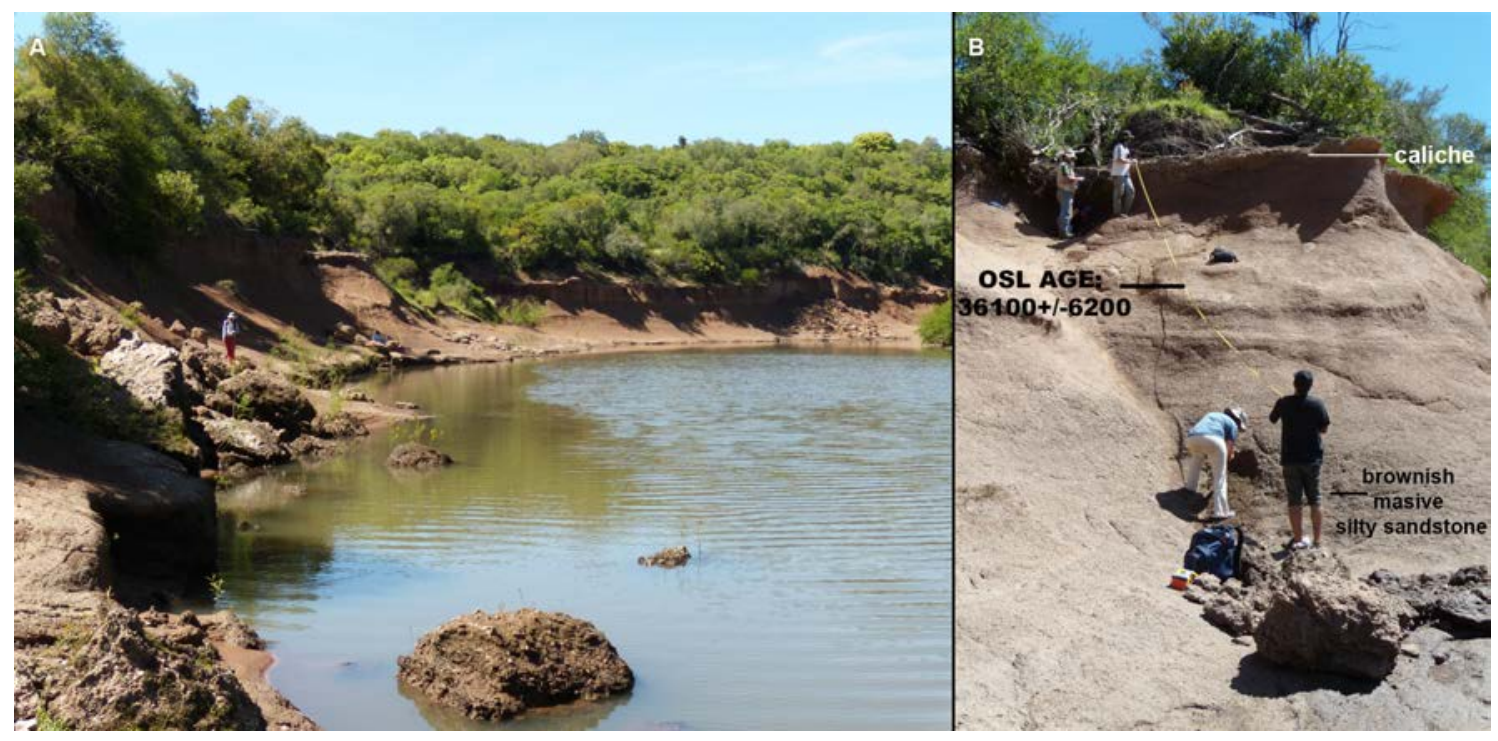

FIG. 2. A. Panoramic view of one of the outcrops of the Sopas Formation on the Cuareim River (Artigas Dapartment, Uruguay); B. Detail of the stratigraphic section from where the new N. recens material described in this work comes from. OSL AGE in years (Optically Stimulate Luminescence Age) from Ubilla et al. (2016).

The microwear analysis consists in the observation and direct counting on the dental surface or a 2D image obtained by scanning electron microscope (SEM) or stereomicroscope, of scars (typically pits and scratches). In herbivores, a high proportion of scratches on pits indicate the consumption of foods with higher content of silica or sand. These scars are caused by the high content of silicophytoliths presents in the walls of grasses, which are the main source of food for grazers (Solounias and Moelleken, 1993; Solounias and Semprebon, 2002). On the other side, a higher frequency of pits on scratches indicates more fragile or delicate food consumption and potential seeds, which characterizes a browser diet. Unlike processing monocotyledons (grass), dicots have few silicophytoliths, whereby the browsers have proportionally few striations. The mixed-feeder regimen displays an intermediate pattern between these two extremes. It is important to point out that since the turnover rate of the abrasion scars is of few days or even daily, the microwear pattern gives us information about food eaten only a few days or hours before the death of the organism (Teaford and Oyen, 1989). A briefly background on microwear studies and the justification in this framework can be seen in the Appendix.

\subsection{Studied materials}

The studied remains correspond to seven adult specimens, all of them with accurate stratigraphic origin and housed at institutional collections of Uruguay and Argentina: Colección Paleontológica de Vertebrados de la Facultad de Ciencias (FC-DPV); Museo de Arqueología y Ciencias Naturales de Salto (MACN-S); Museo Histórico Departamental de Artigas (MHD-P); Museo La Plata (MLP); Museo Argentino de Ciencias Naturales "Bernardino Rivadavia" (MACN-PV) and Museo de Ciencias Naturales de la Región de Ansenuza “Aníbal Montes”, Miramar (MAMM-PV).

FC-DPV 776, right and left partial dentary; Sopas Creek, Salto, OSL ages: 43,500 $\pm 3,600$ and 30,600 $\pm 5,400$ yrs (Ubilla et al., 2016); described by Bond et al. (2001).

MACN-S 92, partial skull; Arapey Grande River, Salto. Late Pleistocene. See complete description in Ubilla et al. (2011).

FC-DPV 749, M2-M3; Malo Creek, Tacuarembó, range ${ }^{14} \mathrm{C}$ cal ages: $33,560-39,900$ yrs (Ubilla et al., 2016). See Ubilla et al. (2011).

MHD-P 509 (new specimen here described, Fig. 3) right and left partial upper dental series and basal 

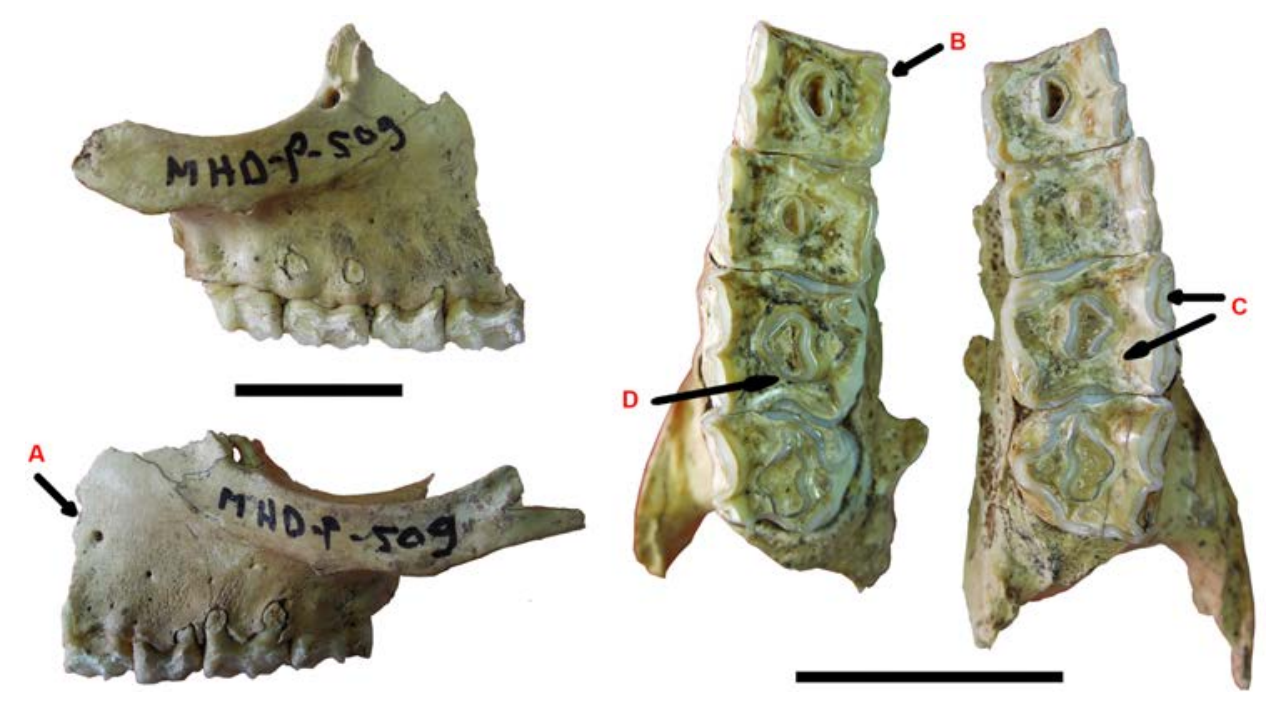

FIG. 3. Neolicaphrium recens from Cuareim River, Artigas, Uruguay (MHD-P 509). Lateral view of right and left side and detail of row teeth in occlusal view. A: Infraorbital foramen at P4 level; B: Developed anterolingual cingulae; C: Cementum in lateral walls and central valleys; D: Metaconule reduced. Scale bar 3 centimeters.

portion of zygomatic; Cuareim River, Artigas, OSL

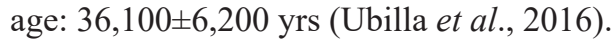

MAMM-PV 098, isolated right $\mathrm{m} 2$; Mar Chiquita Lagoon, Córdoba. Late Pleistocene. Described by Schmidt et al. (2016).

MACN-PV 16603b, isolated right M3; Coronda River, Sante Fé. Late Middle to Late Pleistocene (Iriondo and Kröhling, 2009; Vezzosi et al., in press). Described by Ubilla et al. (2011) as M1-2? of Neolicaphrium sp., designed here as $N$. recens.

MLP 34-V-22-12, holotype of $N$. recens, partial left dentary with $\mathrm{p} 3-\mathrm{m} 3$; Cuarto River, Altos de San Vicente, Córdoba. Middle to Late Pleistocene. See Frenguelli (1921).

\subsection{Methodology}

In this work, we follow the methodology described by Merceron et al. (2004a, 2005). The fossils of Neolicaphrium removed from original stratigraphic position, very fragmented, or immature individuals were not considered. Before beginning the preparation of the dental pieces, it was verified that they did not suffer any type of diagenetic alteration (King et al., 1999), fact that was discarded and allowed to continue without affecting the sample size. The analysis was performed on the second molars (Appendix, Fig. 1), except for one specimen (MACN-PV 16603b) for which we use M3, with the aim of increase the number of studied specimens. For detailed procedures see the Appendix. To avoid errors all the protocol (identification, counting and treatment of images) was carried out by a single operator (AC). The following microwear variables were recorded: total number of scratches, total number of pits, large pits and gouges per $0.09 \mathrm{~mm}^{2}$. We distinguished pit as a scar that have a maximum/ minimum diameter ratio less than four. More elongate features were considered scratches (Gordon, 1982; Merceron et al., 2004a; Mihlbachler et al., 2012). Large pits are deeper than pits, less refractive (always dark), with irregular outlines. Gouges are big scars, with irregular edges, deeper and larger than large pits (Solounias and Semprebon, 2002).

\section{Systematic paleontology}

Order Litopterna Ameghino, 1889

Family Proterotheriidae Ameghino, 1887

Neolicaphrium Frenguelli, 1921

Type Species: Neolicaphrium recens Frenguelli, 1921

Neolicaphrium recens Frenguelli, 1921

Figure 3, Table 1, Appendix Fig. 2.

Referred specimens. MHD-P 509, a partial right and left cheek dentition (P4-M3) with the jugal portion 
TABLE 1. DENTAL MEASUREMENTS OF THE SPECIMEN MHD-P 509.

\begin{tabular}{cccccc}
\hline MHD-P 509 right side & P4-M3 & P4 & M1 & M2 & M3 \\
\hline length & 43.9 & 10.8 & 10.1 & 12.9 & 9.8 \\
width & & 13.7 & 14.8 & 15.5 & 13.4 \\
\hline MHD-P 509 left side & $\mathbf{P 4 - M 3}$ & $\mathbf{P 4}$ & $\mathbf{M 1}$ & $\mathbf{M 2}$ & M3 \\
\hline length & 45 & 10.8 & 9.7 & 12.2 & 12 \\
width & & 13.7 & 14.5 & 16.3 & 14.6 \\
\hline
\end{tabular}

All measurements in millimeters.

of the zygomatic arch and a little part of the lacrimal bone preserved (Fig. 3, table 1). MACN-PV 16603b, isolated right M3 with scarce wear (M1-2? sensu Ubilla et al., 2011) (Appendix Fig. 2).

Locality and age. MHD-P 509: Cuareim River (30³0'44.95”S; 56²0’32.33”'W), Artigas, Uruguay, Sopas Formation, Late Pleistocene. MACN-PV 16603b: Coronda River, Bajo Hondo, Santa Fe, Argentina, late Middle to Late Pleistocene (sensu Vezzosi, 2016).

\subsection{Description}

The teeth of MHD-P 509 are similar in form and size to those described by Ubilla et al. (2011). The series P4-M3 is $45 \mathrm{~mm}$ in length, with all teeth wider than length. The anterior lingual cingulum is developed in P4-M3 and filled with cementum. P4 and $\mathrm{M} 1$ have the highest degree of wearing, being the cusps rounded to blunt in shape. The inner cementum is lost and the dentine is exposed. M1-M3 show variable development of the paracone and metacone folds. M2 is the largest tooth, subquadrangular, with rounded to sharp cusps. The cementum is coating the molars externally, especially M2 and M3 still preserving the inner cementum. In these teeth, the paracone and metacone are the most developed cusps, the postcingulum is sharp and the hypocone is especially reduced in M3. As in the specimen MACN-S 92 the M1-M3 metaconules are reduced as a slight crest. The quantitative comparison of MHD-P 509 with the specimens MACN-S 92 and FC-DPV 749 show that they are closely similar, being the M1 and M2 the less variable teeth, respect to size.

The following set of anatomical features allow assigning this material to $N$. recens: infraorbital foramen located at the P4 level; P4-M3 with a very well developed anterolingual cingulae; cementum covering the lateral walls of P4-M3, central valleys, and part of the occlusal surface; metaconule reduced to a small transverse crest connecting the hypocone to the metacone (Fig. 3).

MACN-PV $16603 \mathrm{~b}$ has been completely described by Ubilla et al. (2011) as Neolicaphrium sp. These authors attribute the differences observed between this specimen and the Uruguayan specimens of $N$. recens (e.g., size, less worn, thick cementum covering many crown features) to age differences, being MACN-PV $16603 \mathrm{~b}$ a younger specimen. Moreover, there are other features to emphasize: 1) The way in which the paraconule, protocone and hypocone are arranged, with the protocone very lingually projected, forming a linguo-distal face of semicircular edge and not so straight as it happens in M1-M2; 2) the complexity of the enamel bands delimiting the mesio-distally elongated central fossa. These characters plus those enunciated by Ubilla et al. (2011) are exclusive of the M3 of $N$. recens, which allows assigning this molar to that taxon.

\section{Results and discussion}

\subsection{Feeding habits}

All microwear data collected from $N$. recens are available in table 2 . The predominant scars observed were small pits (Fig. 4). Some gouges, large pits and fine scratches were also present (Fig. 5). According to Solounias and Semprebon (2002) scratches are more discriminating than pits because there is no overlap in the scratch averages between browsers and grazers. Furthermore, the range of individual scratches is 0 to 
TABLE 2. SUMMARIZE OF MICROWEAR VARIABLES.

\begin{tabular}{lccc}
\hline \multicolumn{1}{c}{ Specimen } & Np & Ns & TN (p+s) \\
\hline FC-DPV 776 & 10 & 1 & 11 \\
FC-DPV 749 & 18 & 0 & 18 \\
MHD-P 509 & 22 & 10 & 32 \\
MACN-S 92 & 20 & 3 & 23 \\
MACN-PV 16603 b & 10 & 0 & 10 \\
MLP 34-V-22-12 & 12 & 0 & 12 \\
MAMM-PV 098 & 11 & 2 & 13 \\
\hline
\end{tabular}

Np: number of pits; Ns: number of scratches; TN: total number of scars per $0.09 \mathrm{~mm}^{2}$.

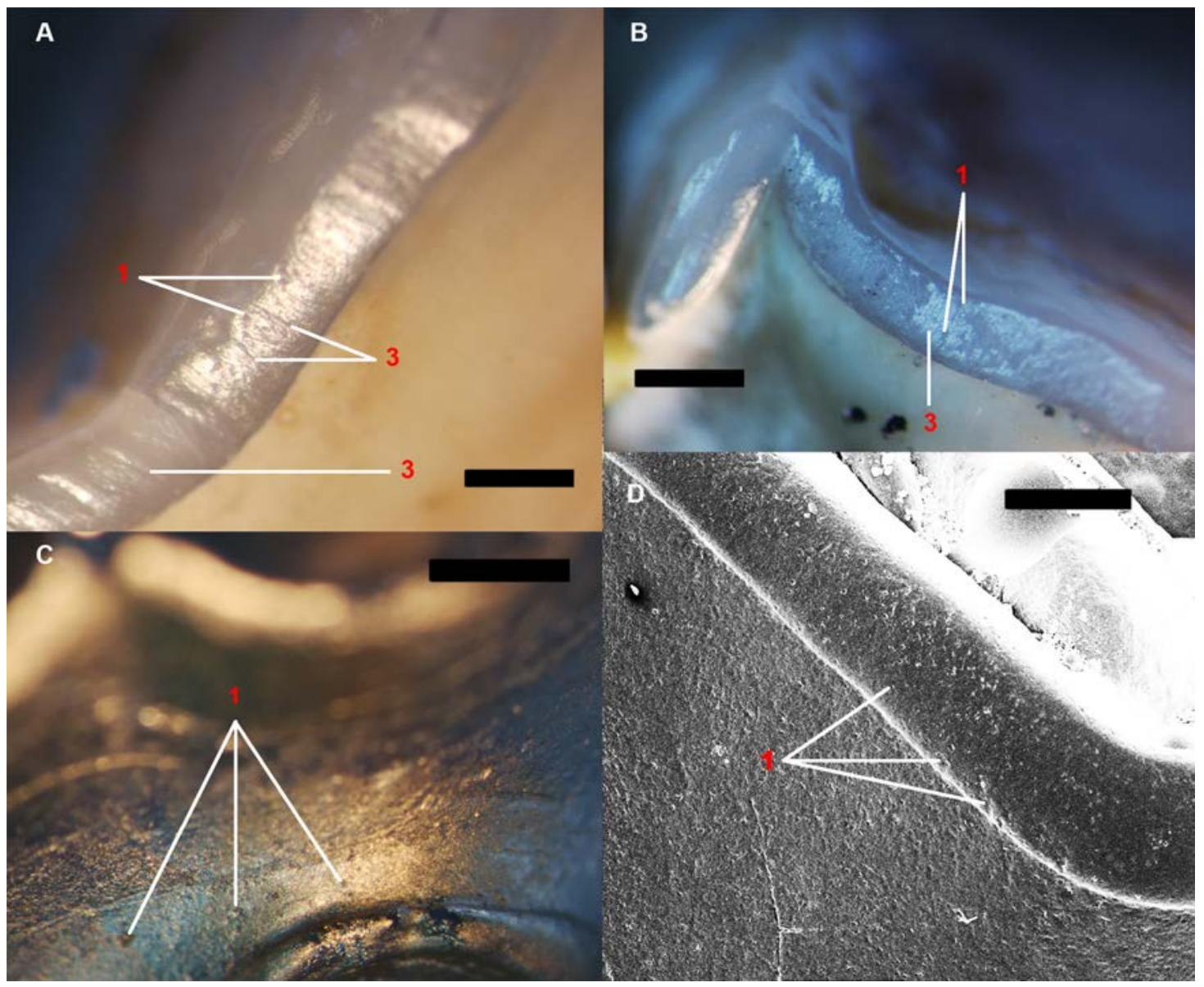

FIG. 4. Tooth surface showing microwear scars. A-B. MHD-P 509 30X; C. FC-DPV 749 30X; D. MACN-S 92 35X. Scale bar 500 micrometers. 1: pits; 3: scratches. 


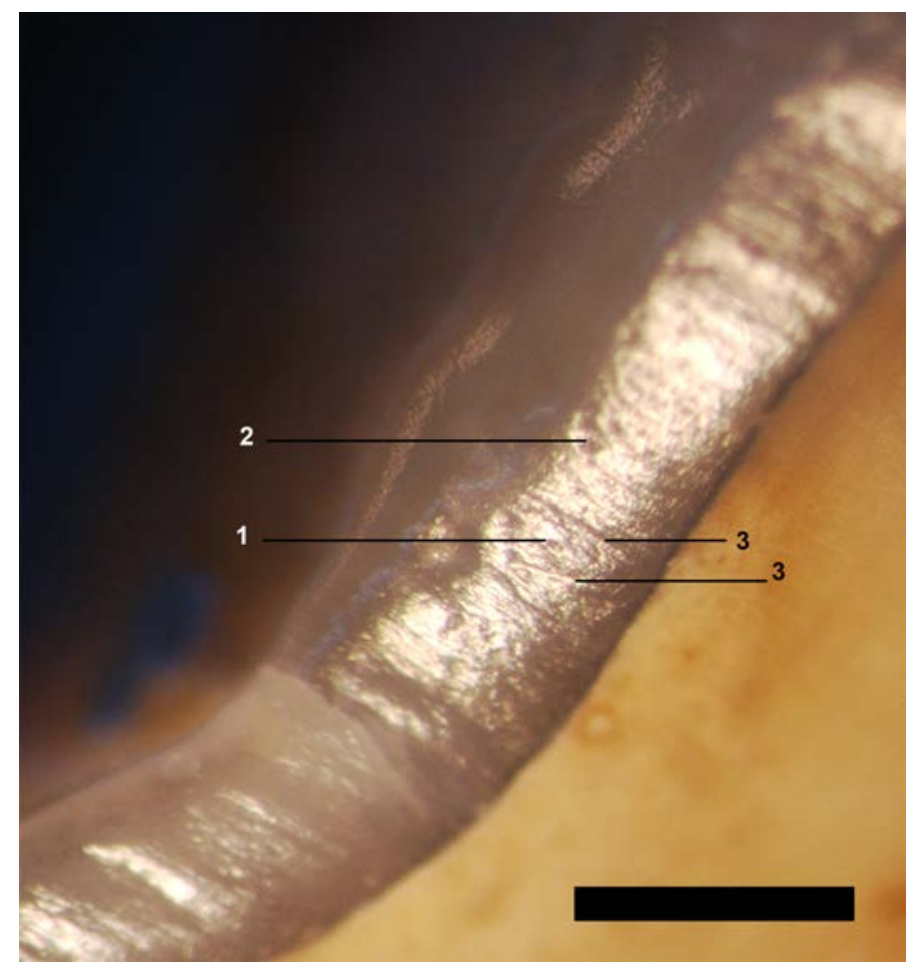

FIG. 5. Detail of microwear of the specimen MHD-P 509 where pits (1), large pits (2) and fine scratches (3) are shown. Scale bar 500 micrometers.

17.5 for browsers and 17.5 to 29 for grazers (Solounias and Semprebon, 2002; Merceron et al., 2004a). The average number of pits overlaps between browsers and grazers, especially at less than 20 pits, so this number alone cannot be taken into account for discriminate browsing from grazing ungulates. The low number of scratches and high proportion of pits observed in the studied specimens (Table 2) are consistent with a browser diet for Neolicaphrium recens.

\subsection{Dietary items}

The microwear pattern recognized to $N$. recens possibly imply low intakes of silicophytoliths (no grass intake) and/or foliar strata with a low percentage of sediment (far from the ground). A diet with that features may probably include soft elements, such as fleshy leaves, buds and stems of trees and shrubs.

$N$. recens did not shows the typical pattern recognized for browser species that ingest heavy (hard) fruits or seeds, for example higher number of scratches than traditional browsers, higher percentages of coarsely or mixed types of scratches than found in traditional browsers or grazers, and very high percentages of large pits (Solounias and Semprebon, 2002).

\subsection{Intraespecific variability}

All the specimens here analyzed belong to the same biological entity but, even that, one of them (MHD-P 509) shows a coherent pattern of some deep pits and fine scratches on both right and left molars. This pattern matches with the evidence provided by the results of carbon and oxygen isotopic studies (Morosi and Ubilla, 2017) indicating a proportion of $\mathrm{C}_{3}$ plants consumption for the specimen MHD-P 509 lower than the other individuals of $N$. recens.

The observed differences in MHD-P 509 respect to the other specimens could have different explanations as the following:

1. The habitat where the specimen MHD-P 509 lived was a more open place respect from where the other specimens come. 
2. Some seasonal changes in the environment could be possible as was demonstrated in the pioneering work of Walker et al. (1978). The change of feeding preferences in response to seasonal changes has been widely documented in extant ungulates. For example, Novello et al. (2010) pointed that the small antelope Tragelaphus scriptus adopts different feeding strategies during the year from young grasses and non-graminoid herbaceous in the wet season, to dicots leaves the rest of the year. There are evidence that support seasonal environment in the deposits of the Sopas Formation, such as the presence of the migrant bird Chloephaga picta and the record of worm aestivation chambers (Castrichnus incolumis) (Ubilla et al., 2016).

3. It is even possible to think that the different wear pattern may be showing simple individual variation. Solounias and Semprebon (2002) stated that the number of scratches can fluctuate widely within the same species: e.g., 0-36; 2.5-51.5 (p. 18).

\subsection{Tooth wear versus gross morphology}

Dental microwear analysis provides insights into the diet of extinct species trough comparison with extant species, being possible to relate dental morphology, the environment and the food composition. However, some contradictions may occur if results are compared with additional evidences. Fraser and Theodor (2011) performed a discriminant analysis to find how well the most commonly used dietary proxies classify ungulates into the main dietary categories (browsers, grazers, and mixed feeders). They found that mesowear and microwear perform better than morphological dietary proxies, though none are strong proxies in isolation.

Traditionally, high-crowned (hypsodont) teeth that are widely found among mammalian herbivores have been assumed as a mechanism for endure wear tooth (due to a higher intake of abrasive food, e.g., grass). In the opposite extreme are the brachyodont or low-crowned teeth. Therefore, a consistent pattern of microwear would be expected: a higher percentage of scratches in relation to pits (grazer) in a hypsodont tooth and a higher percentage of pits on scratches (browser) in a brachyodont one. Nevertheless, Solounias and Semprebon (2002) indicated that some brachyodont species was a mixed feeder-grazer while other hypsodont species was browser (see a full updated discussion in Damuth and Janis, 2011).
The teeth of $N$. recens are mesodont (HI following Janis, $1988=2.00-2.50$ ) and the molariforms are covered with cementum and accordingly is expecting a higher percentage of abrasive scars and a more mixed diet. Bond et al. (2001) suggested that the relatively high values of mesodonty recored for $N$. recens, along with the presence of cementum, are indicators of an adaptation to forested, savanna-like habitats. Actually, this observation is in agreement with the information provided by the associated fauna (Ubilla et al., 2004) and the results of carbon and oxygen isotopic studies (Morosi and Ubilla, 2017).

\subsection{Behavioral plasticity and scale}

Organisms show high behavioral plasticity in diets, which is independent of tooth hypsodonty and must be recognized as a long term adaptation, being related to a different time scale level: microwear is the result of a single organism in his environment and hypsodonty is a condition reached by adaptation during the evolution of the species. In fact, there are many documented inconsistencies in different organisms because different proxies may predict different diets for the same species (see comprehensive review in Davis and Pineda, 2016). Incongruence can be caused by proxies recording diet over vastly different timescales. There are few previous studies of microwear pattern in South American mammals (Notoungulata: Townsend and Croft, 2008; Billet et al., 2009. Gomphoteriidae: Asevedo et al., 2012; Avilla et al., 2014. Cervidae: Rotti et al., 2018). Townsend and Croft (2008) reached the same contradictories results between diet previously inferred by hypsodonty and those based on microwear.

Each proxy records a slightly different aspect of diet (Davis and Pineda, 2016), so we have to think if our results are congruent with the question we made at the beginning of the research, in this case: which were the food preferences of these analised specimens of Neolicaphrium recens? We consider that this questioning has been successfully answered taking into account the number of specimens available and the data obtained from them. This is the first time that a microwear analysis is performed on litopterns, we therefore took a conservative attitude. Even that, there is enough objective evidence to continue increasing the use of this method to the study of these ungulates. 


\section{Final remarks}

The new specimen (MHD-P 509) of Neolicaphrium recens here described correspond to one of the most complete upper dentition materials and with an intermediate tooth wear, which allowed to identify diagnostic characters. They also offered a comparative framework to confirm that the molariform (MACNPV 16603b) primarily assigned to Neolicaphrium sp, corresponds to a M3 of $N$. recens. Both specimens represent new localities where the taxon is recorded, expanding its range of geographical distribution.

The data obtained in our study reveal the feeding habits of seven specimens of Neolicaphrium recens, indicating a browser diet. It must be stated that in the microwear pattern we are only seeing the scars produced by food items ingested just a few days before death. Therefore, this result is very specific and is not indicating a pattern of food preferences over a lifetime of the organism or the result of an adaptive process of the species. This data only show the preferences of the studied organisms confined to a restricted environmental context.

Our results are consistent and complementary with the result of carbon and oxygen isotopic studies performed on $N$. recens specimens restricted to Late Pleistocene of northern Uruguay (Morosi and Ubilla 2016, 2017). The isotopic results show a browser regimen, which means that the carbon incorporated through diet came from $\mathrm{C}_{3}$ plants (predominantly trees and shrubs with a minor portion of grass). This matches with the proposals of environments reconstructed from the fauna associated with $N$. recens, indicating for the Sopas Formation open to semi open grassland with forested areas (tree and shrub vegetation), resembling a wooded savanna (Ubilla et al., 2016). Since our study encompasses a larger geographical area and a larger number of specimens, the results suggest that the taxon is potentially useful as environmental indicator, even though the samples come from different localities, not necessarily contemporaneous.

This is the first microwear analysis on the family Proterotheriidae shedding light to the paleobiology of a Pleistocene species and to the paleoecological and paleoenvironmental reconstruction.

\section{Acknowledgments}

$\mathrm{H}$. Machado kindly helped us with molding process. A. Rojas, J. Soloviy, M. Trindade, A. Kramarz, M. Reguero and C. Alberto Luna allowed the access to the studied specimens. We appreciate the comments of the reviewers L. Dos Santos Avilla and R. Vezzosi, and the Editor W. Vivallo, which significantly improved this work. This is a contribution to the Ph.D. Project of one of the authors, A. Corona. Comisión Académica de Posgrado (grants 2014, 2017); Programa de Desarrollo de las Ciencias Básicas (Pedeciba Biología); Comisión Sectorial de Investigación Científica CSIC-C-211-348 (M. Ubilla); C229-348 (D. Perea), and Agencia Nacional de Investigación e Innovación/Fondo Clemente Estable FCE2011-6572 (D. Perea) provided financial support.

\section{References}

Álvarez, B.B. 1974. Los mamíferos fósiles del Cuaternario de Arroyo Toropí, Corrientes (Argentina). Ameghiniana 11: 295-311.

Ameghino, F. 1887. Enumeración sistemática de las especies de mamíferos fósiles coleccionados por Carlos Ameghino en terrenos eocenos de la Patagonia austral y depositados en el Museo La Plata. Boletín del Museo de La Plata 1: 1-26.

Ameghino, F. 1889. Contribución al conocimiento de los mamíferos fósiles de la República Argentina. Actas de la Academia Nacional de Ciencias de Córdoba 6: 1-1027.

Antón, D. 1975. Evolución geomorfológica del norte del Uruguay. Dirección de Suelos y Fertilizantes, Ministerio de Agricultura y Pesca: 22 p. Montevideo.

Asevedo, L.; Winck, G.R.; Mothé, D.; Avilla, L.S. 2012. Ancient diet of the Pleistocene gomphothere Notiomastodon platensis (Mammalia, Proboscidea, Gomphotheriidae) from lowland mid-latitudes of South America: stereomicrowear and tooth calculus analyses combined. Quaternary International 255: 42-52.

Avilla, L.S.; Asevedo, L.; Mothé., D.; Dantas, T. 2014. Feeding habits of South American gomphotheres (Proboscidea, Gomphotheriidae): a comparative study of proboscidean's paleodiet diversity in the Quaternary. In International Conference on Mammoths and their Relatives, No. 6, Special Volume 102: 25-26. Grevena.

Billet, G.; Blondel, C.; De Muizon, C. 2009. Dental microwear analysis of notoungulates (Mammalia) from Salla (Late Oligocene, Bolivia) and discussion on their precocious hypsodonty. Palaeogeography, Palaeoclimatology, Palaeoecology 274: 114-124.

Bond, M.; Perea, D.; Ubilla, M.; Tauber, A. 2001. Neolicaphrium recens Frenguelli, 1921, the only 
surviving Proterotheriidae (Litopterna, Mammalia) into the South American Pleistocene. Paleovertebrata 30: 37-50.

Covert, H.H.; Kay, R.F. 1981. Dental Microwear and Diet: Implications for determining the feeding behaviors of extinct primates, with a comment on the dietary pattern of Sivapithecus. American Journal of physical anthropology 55: 331-336.

Damuth, J.; Janis, C.M. 2011. On the relationship between hypsodonty and feeding ecology in ungulate mammals and its utility in palaeoecology. Biological Reviews 86: 733-758.

Davis, M.; Pineda Muñoz, S. 2016. The temporal scale of diet and dietary proxies. Ecology and Evolution 6: 1883-1897.

Fraser, D.; Theodor, J.M. 2011. Comparing ungulate dietary proxies using discriminant function analysis. Journal of Morphology 272: 1513-1526.

Frenguelli, J. 1921. Sobre un proterotérido del Pampeano superior de Córdoba, Neolicaphrium recens, nov. Actas de la Academia Nacional de Ciencias de Córdoba 7: 7-23.

Galbany, J.; Martínez, L.M.; López-Amor H.M.; Espurz, V.; Hiraldo, O.; de Juan, J.; Pérez Pérez, A. 2005. Error rates in buccal-dental microwear quantification using scanning electron microscopy. Scanning 27: 23-29.

Gaudioso, P.J.; Gasparini, G.M.; Herbst, R.; Bárquez, R.M. 2017. First record of the Neolicaphrium recens Frenguelli, 1921 (Mammalia, Litopterna) in the Pleistocene of Santiago del Estero Province, Argentina. Papéis Avulsos de Zoologia. Museu de Zología da Universidade de São Paulo 57: 23-29.

Gordon, K.D. 1982. A study of microwear on chimpanzee molars: implications for dental microwear analysis. American journal of physical anthropology 59: 195215. doi: 10.1002/ajpa.1330590208.

Gordon, K.D. 1988. A review of methodology and quantification in dental microwear analysis. Scaning microscopy 2: 1139-1147.

Grine, F.E.; Ungar, P.S.; Teaford, M.F. 2002. Error rates in dental microwear quantification using scanning electron microscopy. Scanning 24: 144-153.

Iriondo, M.H.; Kröhling, D.M. 2009. From Buenos Aires to Santa Fe: Darwin's observations and modern knowledge. Revista de la Asociación Geológica Argentina 64: 109-123.

Janis, C.M. 1988. An estimation of tooth volume and hypsodonty indices in ungulates mammals, and the correlations of these factors with dietary preferences. In Proceedings of the International Symposium on
Dental Morphology, No. 7, Memories, Muséum National d'Histoire Naturelle 53: 367-387. Paris.

King, T.; Andrews, P.; Boz, B. 1999. Effect of taphonomic processes on dental microwear. American Journal of Physical Anthropology 108: 359-373.

Luna, C.A.; Schmidt, G.I.; Ochoa, J.G. 2015. Nuevos registros de Neolicaphrium recens Frenguelli (Litopterna, Proterotheriidae) procedentes de Corralito (Pleistoceno tardío-Holoceno temprano), Córdoba, Argentina. Ameghiniana 53: 20R.

Merceron, G.; Blondel, C.; Brunet, M.; Sen, S.; Solounias, N.; Viriot, L.; Heintz, E. 2004a. The late Miocene palaeoenvironment of Afghanistan as inferred from dental micro-wear in artiodactyls. Palaeogeography, Palaeoclimatology, Palaeoecology 207: 143-163.

Merceron, G.; Viriot, L.; Blondel, C. 2004b. Tooth microwear pattern in roe deer (Capreolus capreolus L.) from Chize (western France) and relation to food composition. Small Ruminant Research 53: 125-132.

Merceron, G.; Blondel, C.; Bonis, L.; Koufos, G.D.; Viriot, L. 2005. A new method of dental micro-wear analysis: application to extant Primates and Ouranopithecus macedoniensis (Late Miocene of Greece). Palaios 20: 551-561.

Mihlbachler, M.C.; Beatty, B.L.; Caldera-Siu, A.; Chan, D.; Lee, R. 2012. Error rates and observer bias in dental microwear analysis using light microscopy. Palaeontologia Electronica 15 (12A): 22 p.

Morosi, E.; Ubilla, M. 2016. Isotopes $\left(\delta^{13} \mathrm{C}\right)$, dietary and environmental inference in Neolicaphrium recens Frenguelli, 1921. In Congreso Latinoamericano de Paleontología, No. 9, Libro de Resúmenes: p. 76. Lima.

Morosi, E.; Ubilla, M. 2017. Dietary and palaeoenvironmental inferences in Neolicaphrium recens Frenguelli, 1921 (Litopterna, Proterotheriidae) using carbon and oxygen stable isotopes (Late Pleistocene; Uruguay). Historical Biology. doi: 10.1080/08912963.2017.1355914.

Novello, A.; Blondel, C.; Brunet, M. 2010. Feeding behavior and ecology of the Late Oligocene Moschidae (Mammalia, Ruminantia) from La Milloque (France): Evidence from dental microwear analysis. Comptes Rendus Palevol 9: 471-478.

Perea, D.; Ubilla, M.; Bond, M. 1995. The Proterotheriidae (Litopterna), surviving ungulates in the Pleistocene. In Jornadas Argentinas de Paleontología de Vertebrados, No. 11, Libro de Resúmenes: p. 25. Tucumán.

Prado, J.; Martínez-Maza, C.; Alberdi, M.T. 2015. Megafauna extinction in South America: a new chronology from the 
Argentine pampas. Palaeogeography, Palaeoclimatology, Palaeoecology 425: 41-49.

Rotti, A.; Mothé, D.; Avilla; L.S.; Semprebon, G. 2018. Diet reconstruction for an extinct deer (Cervidae: Cetartiodactyla) from the Quaternary of South America. Palaeogeography, Palaeoclimatology, Palaeoecology 497: 244-252. doi:10.1016/j.palaeo.2018.02.026.

Ryan, A. 1979a. Wear Striation Direction on Primate Teeth: A scanning electron microscope examination. American Journal of Physical Anthropology 50: 155-168.

Ryan, A. 1979b. A preliminary scanning electron microscope examination of wear striation direction on primate teeth. Journal of Dental Research 58: 525-530.

Scherer, C.; Gregis Pitana, V.; Ribeiro, A.M. 2009. Proterotheriidae and Macraucheniidae (Litopterna, Mammalia) from the Pleistocene of Rio Grande do Sul State, Brazil. Revista Brasileira de Paleontologia 12: 231-246.

Schmidt, G.I.; Luna, C.A; Vezzosi, R.I. 2016. Avances en el conocimiento de los elementos postcraneales de Neolicaphrium Frenguelli, 1921 (Litopterna, Proterotheriidae). In Congreso Latinoamericano de Paleontología, No. 9, Libro de Resúmenes: p. 149. Lima.

Semprebon, G.; Godfrey, L.R.; Solounias, N.; Sutherland, M.R.; Jungers, W.L. 2004. Can lowmagnification stereomicroscopy reveal diet? Journal of Human Evolution 47: 115-144. doi: 10.1016/ j.jhevol.2004.06.004.

Solounias, N.; Moelleken, S. 1993. Tooth microwear and premaxillary shape of an archaic antelope. Lethaia 26: 261-268.

Solounias, N.; Semprebon, G. 2002. Advances in the reconstruction of ungulate ecomorphology with application to early fossil equids. American Museum Novitates: 1-49.

Tauber, A. 2000. Hallazgos de Proterotheriidae (Mammalia, Litopterna) en el Pleistoceno de Córdoba, Argentina. Ameghiniana 37: 157-162.

Teaford, M.F.; Oyen, O.J. 1989. In vivo and in vitro turnover in dental microwear. American Journal Physical Anthropology 80: 447-460.
Townsend, K.E.; Croft, D. 2008. Diets of Notoungulates from the Santa Cruz Formation, Argentina: new evidence from enamel microwear. Journal of Vertebrate Paleontology 28: 217-230.

Ubilla, M.; Perea, D.; Goso Aguilar, C.; Lorenzo, N. 2004. Late Pleistocene vertebrates from northern Uruguay: tools for biostratigraphic, climatic and environmental reconstruction. Quaternary International 114: 129-142.

Ubilla, M.; Martínez, S. 2016. Geology and Paleontology of the Quaternary of Uruguay. Springer Briefs in Earth System Sciences: 77 p. NewYork.

Ubilla, M.; Perea, D.; Bond, M.; Rinderknecht, A. 2011. The first cranial remains of the Pleistocene proterotheriid Neolicaphrium Frenguelli, 1921 (Mammalia, Litopterna): a comparative approach. Journal of Vertebrate Paleontology 31: 193-201.

Ubilla, M.; Corona, A.; Rinderknecht, A.; Perea, D.; Verde, M. 2016. Marine isotope Stage 3 (MIS 3) and continental beds of northern Uruguay (Sopas Formation): paleontology, chronology and climate. In Marine Isotope stage 3 in southern South America, 60 ka B.P.-30 ka B.P. (Gasparini, G.; Rabassa, J.; Deschamps, C.; Tonni, E.P.; editors). Springer: 183205. New York.

Ungar, P.S. 1995. A semi-automated image analysis procedure for the quantification of dental microwear II. Scanning 17: 57-59.

Vezzosi, R.I. 2016. Diversidad de los mamíferos del Pleistoceno de la Provincia de Santa Fe, Argentina: aspectos taxonómicos, bioestratigráficos y paleobiogeográficos relacionados. Mastozoología Neotropical 23: 215-217.

Vezzosi, R.I.; Schmidt, G.I.; Brunetto, E. 2009. Un Proterotheriinae (Proterotheriidae, Litopterna) en el Pleistoceno tardío-Holoceno temprano (Lujanense) de Santa Fe. Ameghiniana 46: 54R.

Vezzosi, R.I.; Brunetto, E.; Zalazar, M.C. In Press. El registro fósil de vertebrados del Cuaternario de Santa Fe (Argentina): primera Actualización. Opera Lillioana.

Walker, A.; Hoeck, H.N.; Pérez, L. 1978. Microwear of mammalian teeth as an indicator of diet. Science 201: 908-910. doi: 10.1126/science. 684415. 


\section{Appendix}

\section{Materials, methods and specimens used in this study}

\section{Methodological background and fundamentation}

The studies of the microwear pattern began in the 70's trying to find correlations between this microscopic pattern and the diet of extant organisms to use this tool as a proxy in fossils (Walker et al., 1978; Ryan, 1979a, b; Covert and Kay, 1981; Gordon, 1982, 1988; Teaford and Oyen, 1989). All these works, even more recent ones, use SEM to visualize the dental surface, a method that is expensive, time-consuming and very dependent of the expertise of the observer. Ungar (1995) developed a software that allow a semi-automated image analysis making more automated approaches feasible. Alternatives methods were developed by Solounias and Semprebon (2002) and Merceron et al. (2004a, b; 2005) which use a stereomicroscope and refracted light to visualize the scars at low magnification (LM: X35 and X30). Solounias and Semprebon (2002) make the counting directly on the tooth's cast surface while Merceron et al. (2004a, b) do it on a high resolution micrograph in the computer, using specific software. These LM's methods are low-cost and faster compared to SEM, allowing a larger number of specimens to be analyzed.

There are some works that have attempted to calculate the error rates associated with the SEM method (Grine et al., 2002; Galbany et al., 2005) and LM method (Semprebon et al., 2004; Mihlbachler et al., 2012). Semprebon et al. (2004) argue that it is possible (and statistically strong) to reproduce the method of identification and counting at LM (X35) by a single researcher as well as by several independent researchers. By the other hand, Mihlbachler et al. (2012) indicate that the inter observer differences are frequent and therefore the comparisons of independent data (meaning a different operator) obtained by the same technic are unreliable.

\section{Specific techniques}

The scars were recorded at the paracone and protoconid (as usually occur in ungulates), and even in the dentine or in the junction dentine-cementum immediately adjacent to that facets (Fig. 1). The teeth were cleaned with a soft brush and etanol, preparing the oclusal surface under stereomicroscopy to ensure the elimination of any kind of glue or sediment particules. In order to preserve the intigrity of the fossils (most of them in a delicate state of conservation), we generated moulds from each piece of interest. The moulds were prepared by double impression (first step: rigid putty; second step: light silicone) with polysiloxane (condensation silicone) impression material and were filled with transparent epoxy resin (60\% resin and $40 \%$ catalyst) to make the casts (Fig. 1). The cast were prepared on a vibratory plate for eliminate bubbles. The polymerization of the resin was $100 \%$ complete after 24 hours. These casts were covered with an ultra thin coating of gold, observed in a Nikon SMZ800 stereomicroscope and photographed at 30X using a Nikon digital sight ds-f1 camera mounted to the stereomicroscopy. Then, the photographs were treated in the computer: a square of $300 \mu \mathrm{m} \times 300 \mu \mathrm{m}\left(0.09 \mathrm{~mm}^{2}\right)$ was defined for quantification, and it was replicate in two different regions of the facets and the mean number was recorded. 


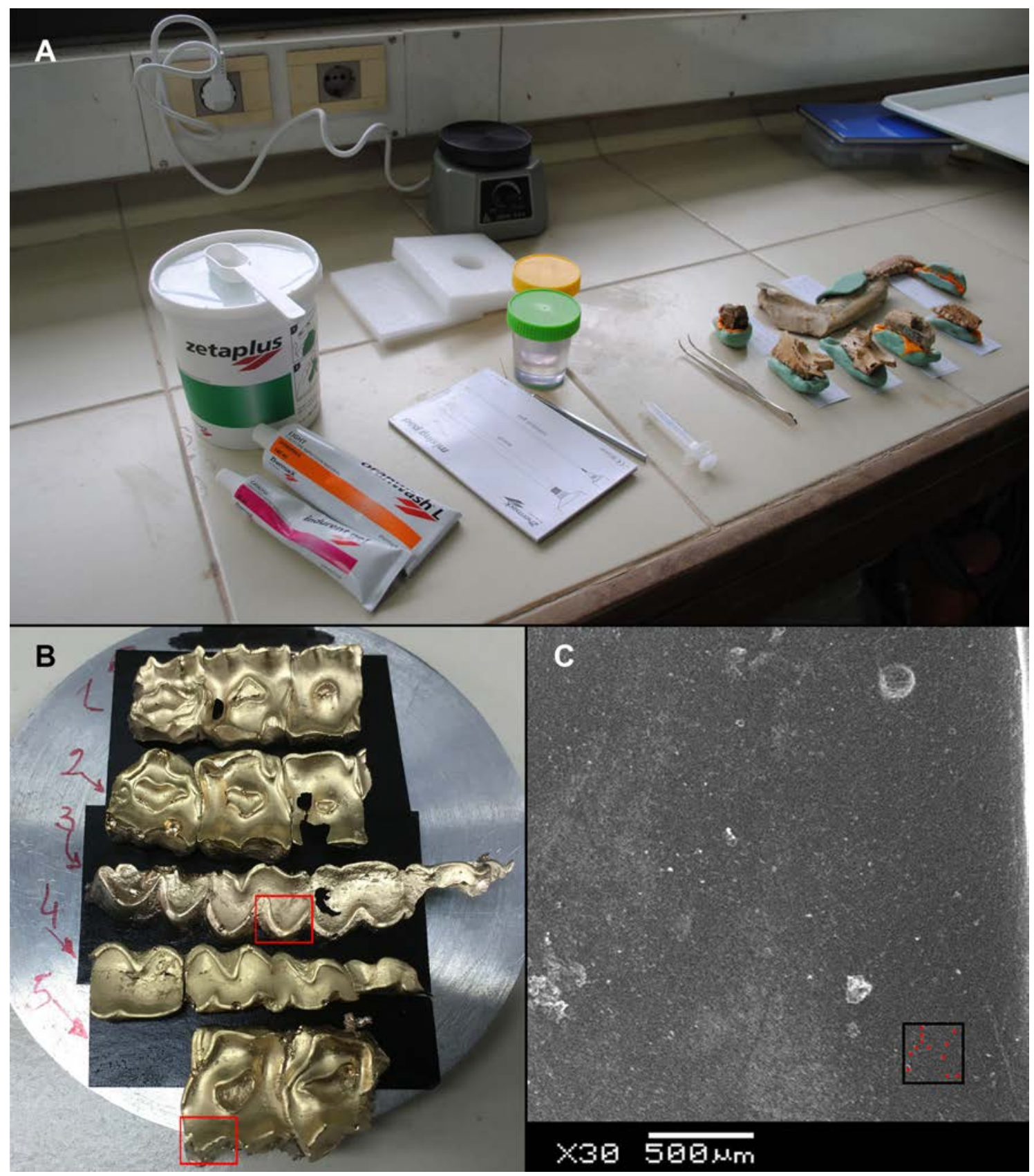

FIG. 1. A. Materials and instruments used in making the moulds; B. Metalized epoxy resin casts showing the analyzed areas (M2 paracone in upper dentition and $\mathrm{m} 2$ protoconid in lower dentition) enclosed in the red squares; $\mathbf{C}$. One of the tooth surfaces (lower dentition) observed showing the area of $300 \mu \mathrm{m}$ x $300 \mu \mathrm{m}$ defined for counting the scars. 
A

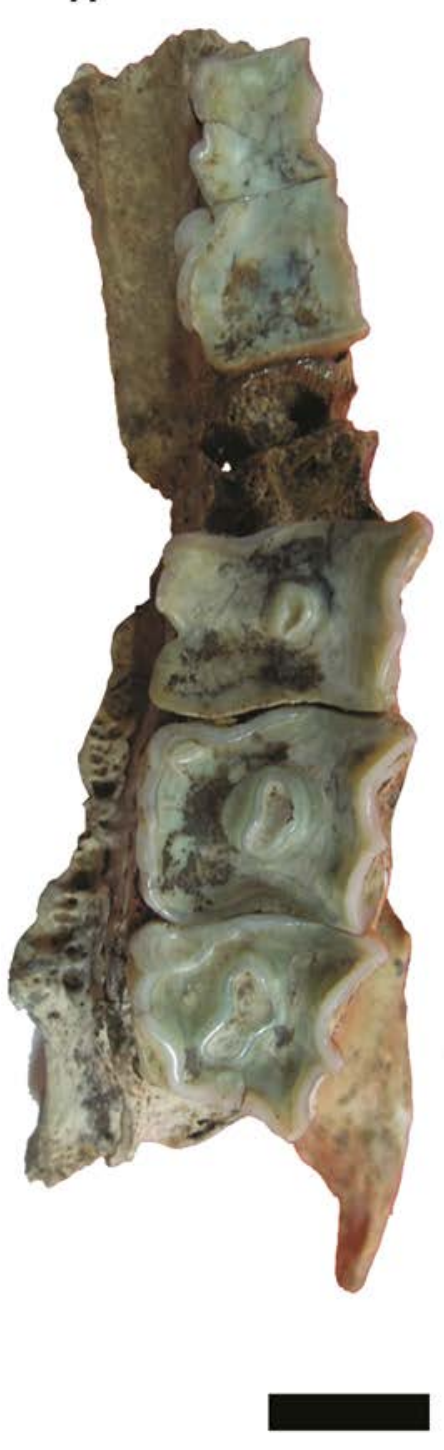

B

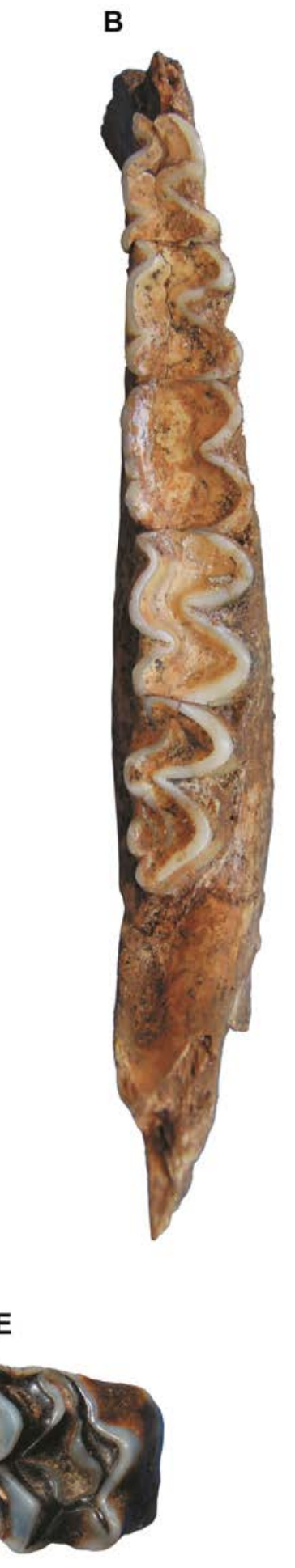

D

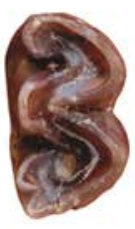

E

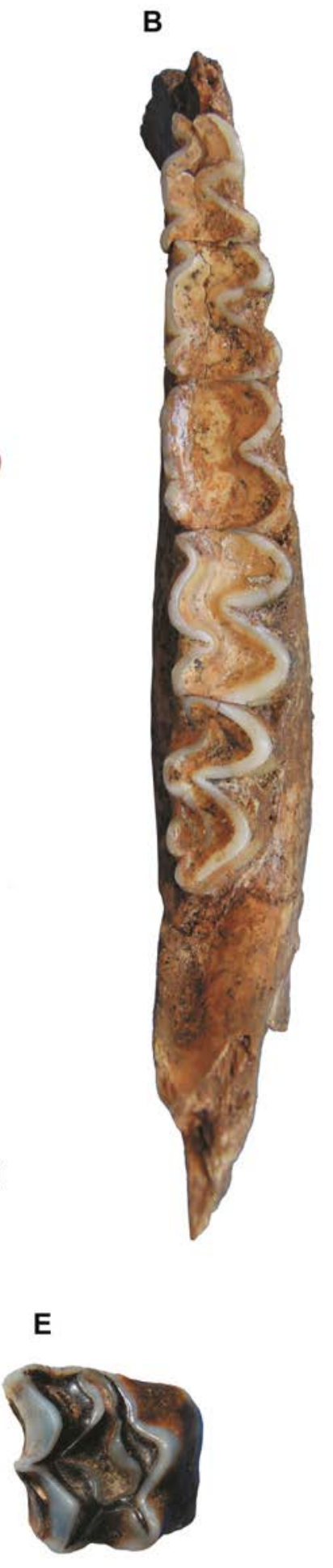

Corona et al./Andean Geology 46(1): 153-167, 2019
C

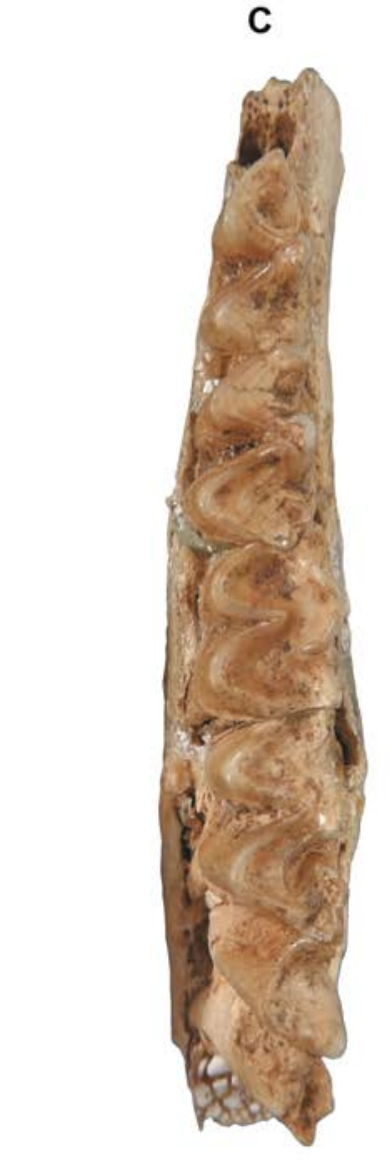

.

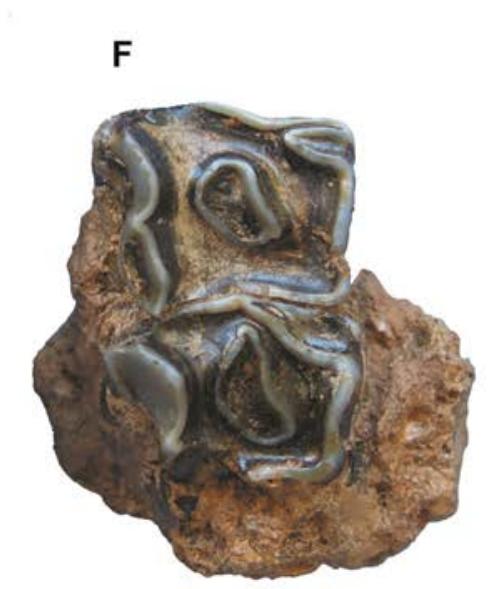

FIG. 2. Photographs of the specimens of Neolicaphrium recens used in this study. A. MACN-S 92; B. FC-DPV 776; C. MLP 34-V-22-12, holotype of N. recens; D. MAMM-PV 098; E. MACN-PV 16603b; F. FC-DPV 749. Scale bar: 1centimeter. 